\title{
Renewable Energy Transition Strategy for PT.CI to Reduce 50\% Emission by 2030
}

\author{
Enrico Yushardi Hamdani ${ }^{1}$, Agung Wicaksono ${ }^{2}$ \\ ${ }^{1,2}$ School of Business and Management Institut Teknologi Bandung
}

\begin{abstract}
The global and Indonesia energy trend is heading to process of transitioning from fossil fuel to renewable energy (decarbonization) in the purpose of reducing Green House Gas (GHG) effects. Industries as one of the biggest contributors of emission generator expected to participate in this effort, where fuel and electricity play significant roles in running the operation. Many businesses try to participate and state their commitment on this energy transition initiative by increasing the portion of renewable energy within their operation. Meanwhile, business have several uncertainties' on how the renewable energy will be acquired and will this renewable energy options be available at the time they need it. Campur Plc. (CP) through its subsidiary in Indonesia, PT. Campur Ilmiah (PT. CI) has targeted the entity to reduce 50\% of the emission by 2030 with the baseline of 2018 , which align with corporate target of $46.2 \%$ of emission reduction globally. Uncertainties on achieving this target generated from external and internal factors, and not to forget how to sustainably maintain the achievement. The location of PT.CI in industrial estate need to be considered as limitation because the power and energy supply are regulated. The accessibility, availability and affordability of renewable energy are expected to be handled by the government, industrial estate or other third party in energy business, but the phasing and the achievement up to now has not shown a promising progress. As a business, PT.CI need to have a strategic planning on this energy transition to support the global target as well as shown a positive investment climate in Indonesia. There are four (4) scenarios has been developed and each of the scenarios are explored to identify alternative and possible strategies to still be able achieving the target and how the organization manage these changes. As the conclusion of this research, four (4) strategic imperatives are defined. This research also might be use as the reference of future planning for the similar industries that have the similar target and type of energy mix.
\end{abstract}

KEYWORDS: Energy Transition, Energy Mix, Emission Reduction, Renewable Energy, Scenario Planning, Similar Industries.

\section{INTRODUCTION}

Refer to global data of greenhouse gas (GHG) emission by sector in 2016, energy contributed $73.2 \%$ of GHG emission with energy used in the industry take $24.2 \%$ of it. Furthermore, Chemical Industry also contributed another $2.4 \%$ of GHG emission globally. Campur Plc. (CP) is a UK based company focus in create, make and sell specialty chemicals that deliver real benefits to a range of diverse products including health and beauty, engine lubricants, plastics and many more, is one of the companies that refer to The United Nation Sustainable Development Goals (UNSDG) a key part in shaping their strategy for a sustainable business. CP commitment to science-based targets and the UN SDGs, by 2030 CP will be Climate, Land and People Positive, with one of the strategies was to reduce $46.2 \%$ GHG emission from all their operating sites by 2030. As part of CP Plc., PT Campur Ilmiah (PT. $\mathrm{CI})$ also challenged and mandated to participated in this global strategy by reducing 50\% GHG emission from our Indonesia manufacturing facility, with Year 2018 used as basis comparison for this reduction.

PT CI is a company located in West Java, specifically in XYZ Industrial Estate where electricity supply in this Industrial Estate has 2 main power suppliers, they are PT ABC (a state own enterprise) through PPA agreement with PT XYZ Power (a private energy company own by XYZ Industrial Estate) and PT Private Listrindo (a private energy company). Meanwhile, for fuel there are two options, there are diesel oil and natural gas and since PT. CI only use natural gas, the potential suppliers currently available in the industrial estate are PT. DEF (a state own enterprise) and PT. BBM (a private energy supplier). PT. CI need a good strategy for this energy transition to get the best conditions desired by the group as one of the requirements of group investment, as well as support the national GHG reduction target, where currently the location of Indonesia operation have very limited sources of alternative energy. By conduct a scenario planning on development of PT. CI growth strategy, especially in accommodating GHG emission target by the group globally, this research expected to have proper planning to face future challenge and condition. 


\section{International Journal of Current Science Research and Review}

ISSN: 2581-8341

Volume 05 Issue 01 January 2022

DOI: 10.47191/ijcsrr/V5-i1-09, Impact Factor: 5.825

IJCSRR@ 2022

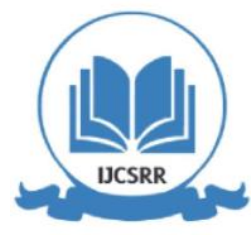

WWw.ijcsrr.org

\section{LITERATURE REVIEW}

\section{Conceptual Framework}

For issue identification, analysis and exploration will refer to AFI framework, where the description is a model that links three independent strategic management tasks (Analyze, Formulate, and Implement) that together help managers plan and implement as strategy that can improve performance and result in competitive advantage". (Strategic Management $3^{\text {rd }}$ Edition, Rothaermel).

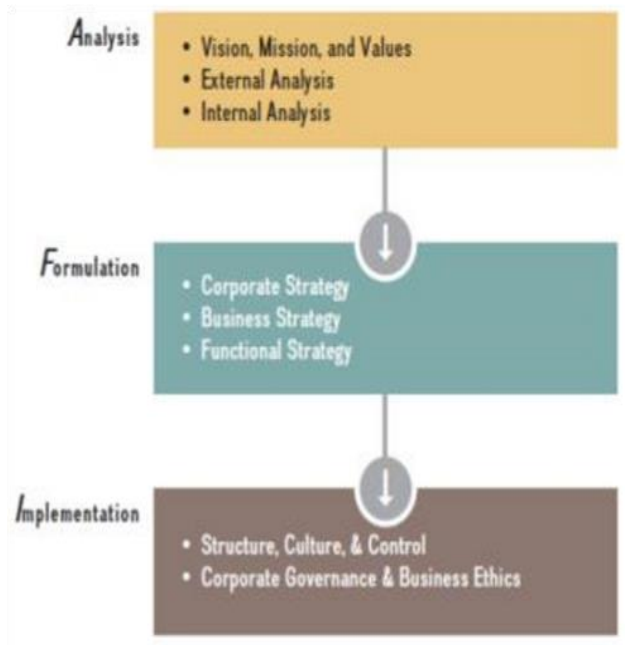

\section{Analysis}

The analysis will be using PESTEL and Porter's Five Forces Model to get more understanding about the condition of the macro external environment. For the internal, the analysis will explore about the resources, capabilities, core competencies and SWOT. PESTEL analysis provides a comprehensive arrangement of several external influencers. According to Johnson \& Scholes (2008), the acronym of PESTEL are Political, Economic, Sociocultural, Technological, Environmental, and Legal factors that provides an analysis on correlation of external factors to the firm. PESTEL provides a relatively straightforward analysis to scan, monitor and evaluate the importance of external factors and trend, that might affect the firm. Depending on strategy of the firm, these factors will influence the company performance in both positive and negative terms (Johnson \& Scholes, 2008).

Porter's Five forces is a model to conduct analysis of an industrial structure. Originally developed by Harvard Business School's Michael Porter in 1979, the five forces model looks at five specific factors that help to determine whether a business can be competitive or not, compared to other business in the industry. Five Forces is considered to understand both competitive strengths and the overall structure of the industry as crucial to the effectiveness of the strategic decision making. Identifying the potential or attractiveness of an industry, provides the foundation for bridging the gap between a company's external environment and its internal resources.

The core competencies definition is a resource or capability that gives a firm competitive advantage. Core competencies are the business functions or operational activities that a company does best. A company's resources are the operational inputs that allow it to perform its business activities A company's capabilities are the activities and functions it performs to utilize its resources in an integrative fashion. SWOT analysis is a structured and strategic planning method used to determine the factors that support achievement, in this case, the strengths, weakness, opportunities and threats involved in a project or business (Albert Humphrey, 2005). By identifying all of these internal aspects, you can use it to develop strategic planning objectives to sustain and grow your business.

\section{Formulation}

Scenario planning is a tool that can be used to help the company preparing for future uncertainties. Scenario planning is not a forecast but future projection of current conditions (Lindgren \& Bandhold, 2009). It is an effective tool to be used to help developed strategies for the medium to long terms. Scenario planning helps companies sharpen the strategy and assist in making strategies for the possibility of an unpredictable future. 


\section{International Journal of Current Science Research and Review}

ISSN: 2581-8341

Volume 05 Issue 01 January 2022

DOI: 10.47191/ijcsrr/V5-i1-09, Impact Factor: 5.825

IJCSRR@ 2022

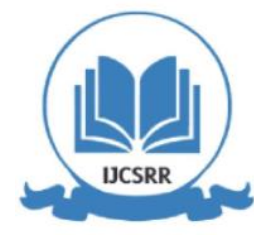

WwW.ijcsrr.org

Scenario planning investigates several uncertainties simultaneously, it involves subjective interpretation as well as objective analysis, the techniques is particularly useful in situation where uncertainty and change are high (Garvin \& Levesque, 2006). Scenario Planning address both optimistic and pessimistic future. It will show several detailed and executable strategic plans. In AFI Framework with continuous feedback loop, scenario planning placed to connect between formulation and implementation, back to analysis again.

\section{Implementation Plan}

To make sure that every plan being executed as designated, change management is required. Change management is a systematic process of applying knowledge, tools, and the resources needed to effect change in the people who will be affected. One of the change management models is ADKAR which developed by Prosci in 1998 after doing some research with more than 300 companies that conducting a major change in their projects. In ADKAR there are five elements which are a process for make changes namely awareness, desire, knowledge, ability, and reinforcement.

The goals or purposes defined by ADKAR are sequential and cumulative where any individual must cover all element in sequence order to make sure the change implemented and sustain as per the target.

\section{METHODOLOGY}

To create a valuable input in the scenario planning process, the composition of the respondent needs to heterogenous coming from different role and background to enrich the scenario planning discussion. To determine the prospective respondent for this research, the key stakeholder of PT. CI energy transition project and in this research, author gathered the data from respondents among the stakeholders (inside and outside the company) to give their valuable view and input for the analysis.

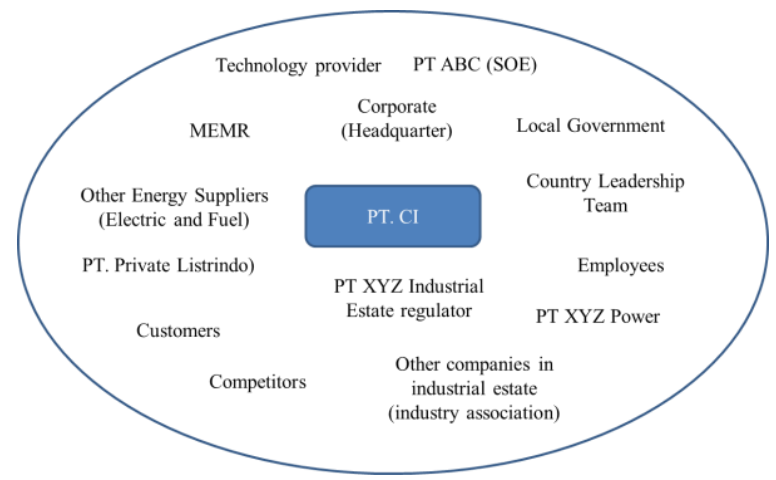

Figure 1. PT. CI Stakeholders Analysis

\section{External Analysis}

PESTLE analyse the following individual components: political, economic, social, technological, legal and environmental, hence PESTLE. This framework executed by understanding of the dynamics related to energy and renewable energy in Indonesia. Further author also reviewing the technology available in the market and review it in accordance with its availability and possibility to adopt by PT.CI or other industry that located in industrial estate zone.

Further Porter Five Forces used to capture the supply and demand related to this renewable energy in correlated with industrial estate, supplier available currently, as well as demand from the tenant in industrial estate by the time limit of 2030. This method used to see the risk and opportunity for PT.CI in achieving the target of energy transition by 2030.

\section{Internal Analysis}

The internal analysis involved several internal professionals to give more view on the aspects identified.

This analysis helps organizations get visibility on their status, letting them understand and measure overall business performance and can help company to have better planning to execute the planning and meet the targets. Further, ADKAR also used to identify the readiness of the organization in facing the changes from this energy transition project. 


\section{International Journal of Current Science Research and Review}

ISSN: 2581-8341

Volume 05 Issue 01 January 2022

DOI: 10.47191/ijcsrr/V5-i1-09, Impact Factor: 5.825

IJCSRR@ 2022

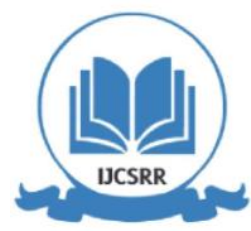

WwW.ijcsrr.org

\section{FINDINGS AND ARGUMENT}

Several uncertain driving forces, which can restrain or allow in the future that have not been revealed, then the two are seen as influential based on the uncertainty matrix (impact and uncertainty level). The two driving forces are Factory Expansion and External Investment (for Renewable energy).

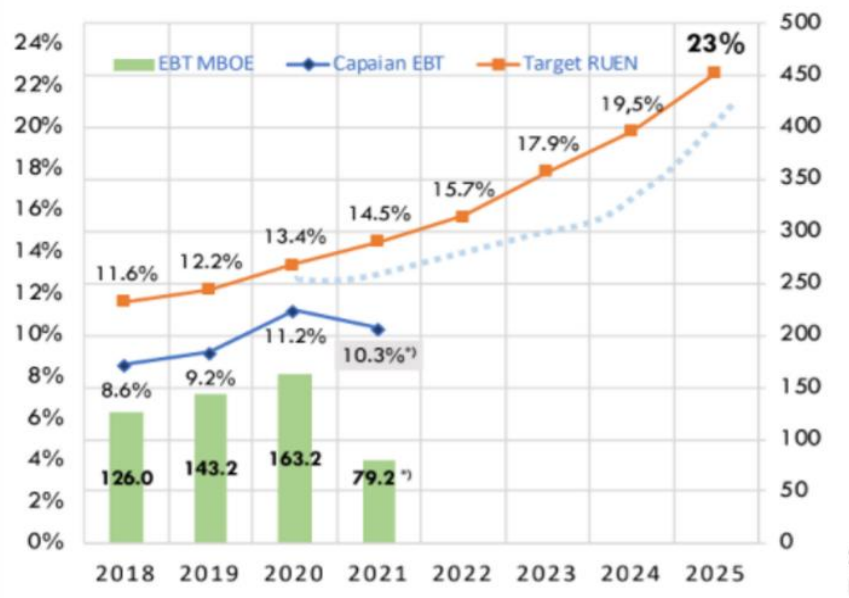

(Source: Corporate Renewable Procurement, 2021)

Figure 2. Indonesia Electrical Energy

Mix Achievement up to 2021

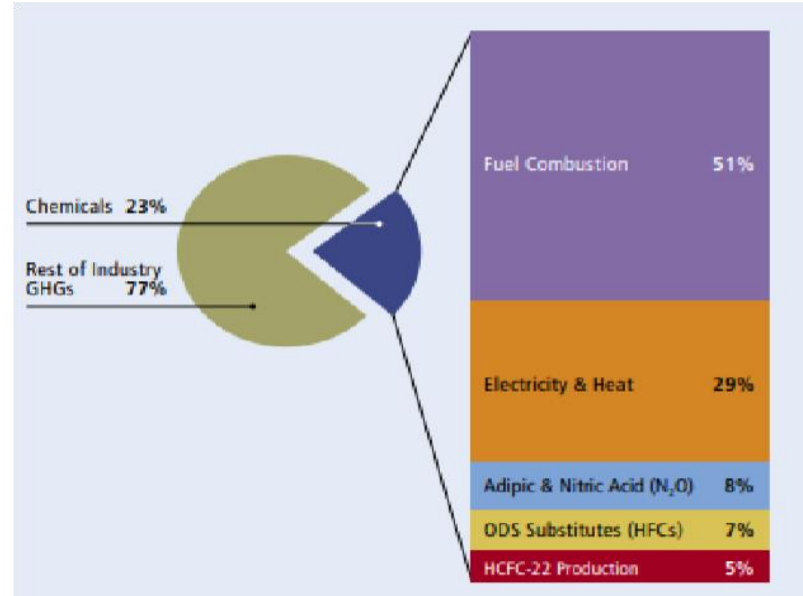

(Source: Enerdata, 2020)

Figure 3. Chemical Industry Typical Energy Mix

From the collected data, it shown that $29 \%$ GHG reduction from Indonesia Government will also still far behind the PT.CI target which is $50 \%$ GHG reduction coming from energy. This is because as mentioned in RUPTL and RUKN, the emission reduction target from Renewable Energy, majorly was coming from electricity source generation is 23\% in 2025 and $29 \%$ in 2030 . Mean while, the typical energy mix of chemical industry coming from fuel combustion, means that despite focusing only to emission from electrical, company also need to keep attention on fuel combustion alternative. The weakness identified is that PT. CI energy usage, including fue usage still considered small, resulting economic review for investment in Indonesia for renewable energy become less interesting. Renewable energy provider required specific minimum usage that PT. CI cannot fulfilled and causing PT. CI to have less option on the renewable energy solution. This analysis resulting four (4) scenarios as below:

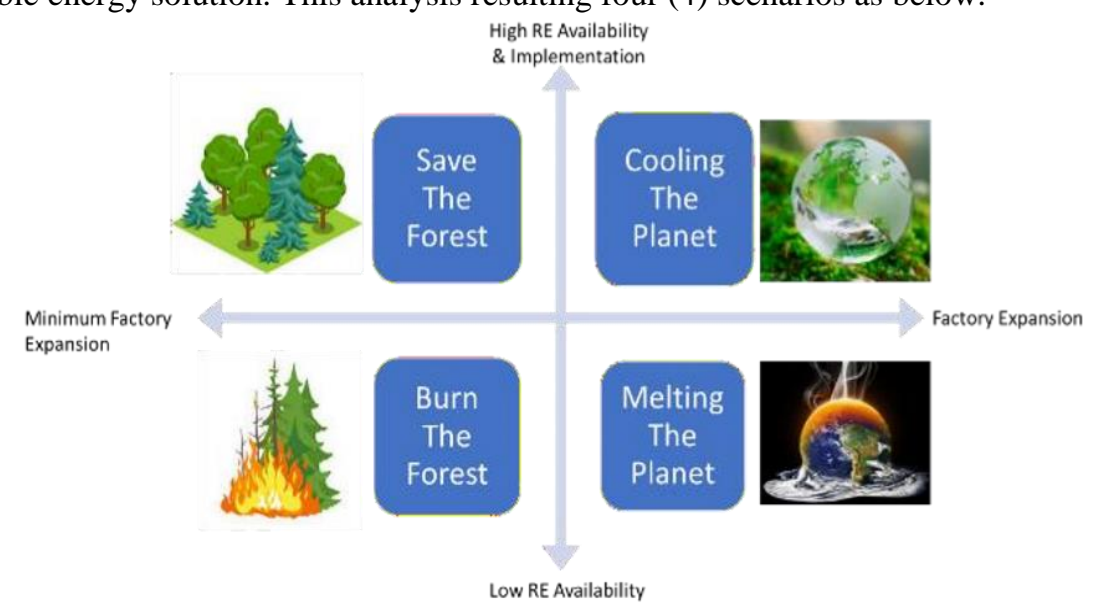

Figure 4. Scenario Matrix of PT.CI

Despite of the technical changes, author also collected internal data from the employee on the readiness of this change coming from energy transition project using ADKAR approach. As the result, managerial level have shown a igh awareness but still lack in 


\section{International Journal of Current Science Research and Review}

ISSN: 2581-8341

Volume 05 Issue 01 January 2022

DOI: 10.47191/ijcsrr/V5-i1-09, Impact Factor: 5.825

IJCSRR@ 2022

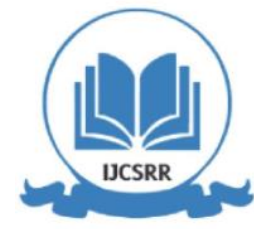

www.ijcsrr.org

designing the way how the project should be done, meanwhile the staff level were identified not knowing much on the changes purpose. The organization is better able to initiate and communicate thorougly to success and sustain a major change. Staff in organizations that are ready for change are more likely to exert greater effort, persist in the face of obstacles, and display cooperative behavior.

\section{CONCLUSIONS}

Current policy and strategies applied by the Indonesia government seems way behind the target defined by PT.CI and directed by CP globally. There many driving forces which could affect the pace of energy transition project in PT.CI, such as electricity price, government regulation, environmental issue, technology, factory expansion, political condition, External investment (RE availability) and the industrial estate regulation. The main target of PT.CI is regarding the strategy of PT.CI to achieves 50\% emission reduction in the next 10 years (2030).

There are some open options available as efforts to achieve this 2030 target for PT.CI, but however the pace will be determined by internal and external factors. The current possible options are to install a solar PV as part of electricity source as well as purchase of unbundled IREC considered the most reasonable options so far. These actions will not be enough, and some CAPEX still needed in the purpose to replace some natural gas fuelled equipment with electrically powered along with purchased IREC.

Table 1. Simulation of Emission Reduction

\begin{tabular}{|c|c|c|c|c|c|c|c|}
\hline \multirow[t]{2}{*}{ Item } & $\begin{array}{l}\text { Baseline } \\
2018\end{array}$ & 2030 & $\begin{array}{l}\text { Government } \\
\text { effort only }\end{array}$ & $\begin{array}{l}\text { Solar } \\
\text { PV }\end{array}$ & IREC & $\begin{array}{l}\text { After } \\
\text { action }\end{array}$ & \multirow[t]{2}{*}{$\begin{array}{l}\% \quad \text { Figure } \\
\text { reduction }\end{array}$} \\
\hline & \multicolumn{6}{|c|}{ CO2 (te per year) } & \\
\hline Electric & 162 & 419 & -121.51 & -125.7 & -171.79 & - & $-100 \%$ \\
\hline Fuels & 198 & 1116 & 0 & 0 & 0 & $1,116.0$ & $464 \%$ \\
\hline Total & 360 & 1535 & -121.51 & -125.7 & -171.79 & $1,116.0$ & $-27 \%$ \\
\hline \multirow[t]{2}{*}{ Item } & $\begin{array}{l}\text { Baseline } \\
2018\end{array}$ & 2020 & $\begin{array}{l}\text { Government } \\
\text { effort only }\end{array}$ & $\begin{array}{l}\text { Solar } \\
\text { PV }\end{array}$ & IREC & \begin{tabular}{|l|} 
After \\
action
\end{tabular} & $\begin{array}{l}\% \quad \text { Figure } \\
\text { reduction }\end{array}$ \\
\hline & \multicolumn{6}{|c|}{ CO2 (te per year) } & \\
\hline Electric & 162 & 176 & -51.04 & -52.8 & |-72.16 & - & $-100 \%$ \\
\hline Fuels & 198 & 309 & 0 & 0 & 0 & 309.0 & $56 \%$ \\
\hline Total & 360 & 485 & -51.04 & -52.8 & -72.16 & 309.0 & $-36 \%$ \\
\hline
\end{tabular}

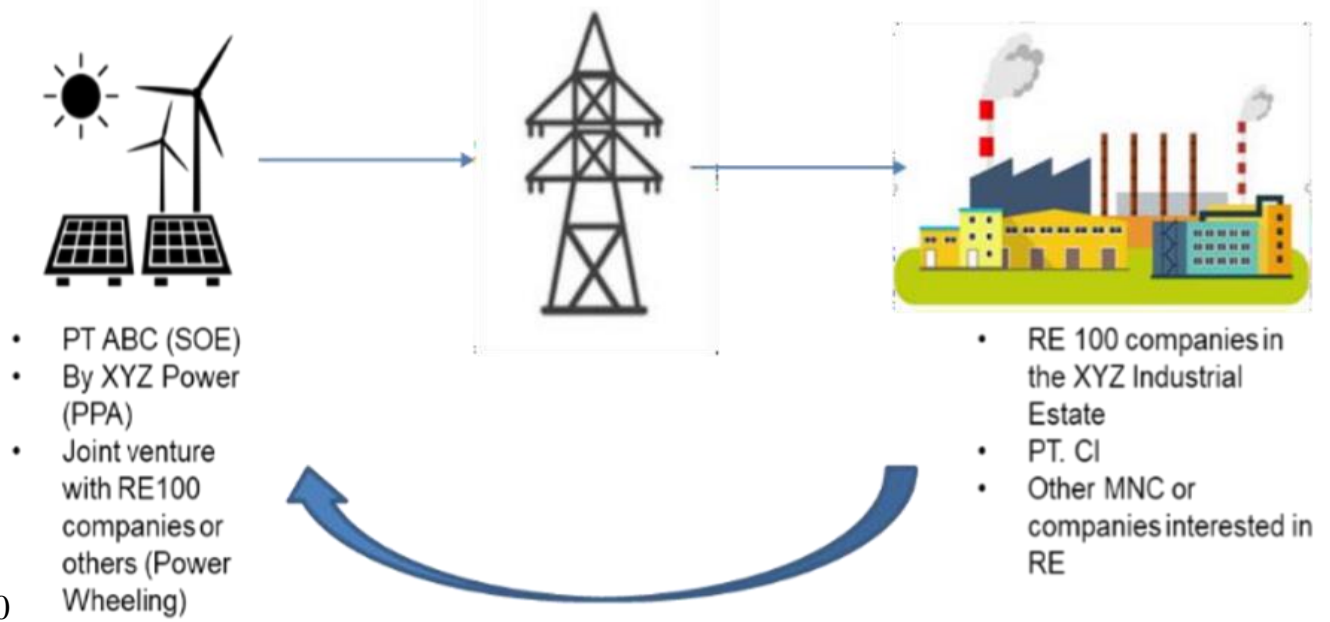

Figure 5. Example on Renewable Energy of PT.CI (+ Solar PV \& IREC) Collaboration 


\section{International Journal of Current Science Research and Review}

ISSN: 2581-8341

Volume 05 Issue 01 January 2022

DOI: 10.47191/ijcsrr/V5-i1-09, Impact Factor: 5.825

IJCSRR@ 2022

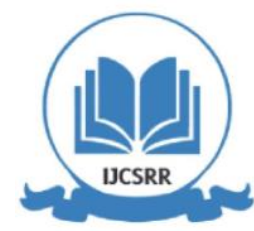

WWW.ijcsrr.org

A scheme of PPA or Power Wheeling is an option that should be considered by PT. CI and with some of RE100 company located in XYZ Industrial Estate, this scheme might me feasible and worth to explore.

The 2030 target to reduce emission by $50 \%$ is achievable only if PT.CI would like to spend some CAPEX on equipment replacement. Meanwhile, if CAPEX is a concern and need to minimise, the reasonable target of emission reduction by 2030 for PT.CI is $27-36 \%$ (based on simulation of government effort + solar PV and IREC) depend on the expansion scheme performed by PT.CI.

It also considers a reasonable number for surrounding similar scale of industry that have the same target but with majority energy come from fossil fuel such as natural gas such as chemical, petrochemical, paint, etc. For industry that use more electricity rather than natural gas/diesel oil, such as electronic, consumer goods, etc, higher percentage can be considered through IREC purchase. For bigger industry scale, PPA (Power Purchase Agreement) will be more sustainable and preferable rather than REC purchase. The research identified some key recommendations from internal and external,that will help PT.CI facing the uncertainty in the scenarios, which will impact the status of achievement of PT.CI in terms of emission reduction and energy transition project:

1. Re-review the scenario planning 5 years from now, to update and validate the condition identified. This will make the scenario become more beneficial for the company to have.

2. Keep tracking the early warning signals for PT.CI energy transition scenarios.

3. Engage communication and relationship with industrial estate, government and other MNCs (especially RE100 companies) that have the same target to make sure that when the condition and opportunity reach the position where it become feasible to create a joint venture in energy, readiness will be the key.

4. Engage with more than one RECs suppliers and technology owner, in order to have more options and more sustainable supply in the future.

5. Increase the awareness and acknowledge the importance of this energy transition project. Further, knowledge management and technology sharing between country and levels is very important

\section{REFERENCES}

1. Agus Tampubolon (2020). Rencana Umum Energi Nasional (RUEN): Existing Plan, Current Policies Implication, and Energy Transition Scenario. IESR

2. Anshar M., Nasir Ani, F., Saman Kadir, A. (2015). Electrical energy potential of rice husk as fuel for power generation in Indonesia. MUCET 2015

3. Arief Wijaya, Hanny Chrysolite, Mengpin Ge, Clorinda Kurnia Wibowo, Almo Pradana, Andhyta Firselly Utami, and Kemen Austin

4. (2017). HOW CAN INDONESIA ACHIEVE ITS CLIMATE CHANGE MITIGATION GOAL? AN ANALYSIS OF POTENTIAL EMISSIONS REDUCTIONS FROM ENERGY AND LAND-USE POLICIES. World Resources Institute

5. Baumert, K. A., Herzog, T. \& Pershing, J. (2005). Navigating the Numbers: Greenhouse Gas Data and International Climate Policy. World Resources Institute.

6. CEIC Data; Indonesia's Central Bureau of Statistics; Conference Board Total Economy Database; International Monetary Fund Cohen, T., \& Jones, P. (2018) Future scenarios for TEN feeder routes 1.769276

7. Cukup Mulyana, Asry Peni Wulandari, Darmawan Hidayat, et al. (2016). Development of Indonesia corncob and rice husk biobriquette as alternative energy source .AIP Conference Proceedings 1712, 050014 (2016);

https://doi.org/10.1063/1.4941897 Published Online: 24 February 2016

8. Dani, Sapuan, (2018). CHALLENGES AND POLICY FOR BIOMASS ENERGY IN INDONESIA. International Journal of Business, Economics and Law, Vol. 15

9. Dewan Energi Nasional Republik Indonesia. (2020). Perkembangan Bauran Energi Primes Nasional Tahun $2015-2019$. Dewan Energi Nasional Republik Indonesia

10. Donald C. Hambrick and James W. Fredrickson. (2005) Are you have a strategy? Academy of Management Executive, 2005, Vo;.19, No. 4, 19 (4)

11. Enerdata. (2020). Global Energy and CO2 data. Grenoble, France. https://www.enerdata.net/research/energymarket-dataco2emissions-database.html 


\section{International Journal of Current Science Research and Review}

ISSN: 2581-8341

Volume 05 Issue 01 January 2022

DOI: 10.47191/ijesrr/V5-i1-09, Impact Factor: 5.825

IJCSRR @ 2022

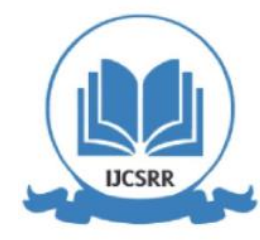

www.ijcsrr.org

12. Fuentes-Bracamontes, R. (2016). Is unbundling electricity services the way forward for the power sector? Electricity Journal, 29(9), 16-20. https://doi.org/10/1016/j.tej/2016.10.006

13. Garvin, D.A., \& Levesque, L. C. (2006). A Note on Scenario Planning. Harvard Business School Government of Indonesia (2017) Third National Communication of Indonesia under the UNFCCC. https://unfccc.intnational_reports/non-annex_i_natcom/items/10124.php

14. Hannah Ritchie and Max Roser (2020) - "CO 2 and Greenhouse Gas Emissions". Published online at OurWorldInData.org.

15. Hiatt, Jeffrey M. (2006), ADKAR: A Model for Change in Business, Government and Our Community. Prosci

16. Humphrey, Albert. SWOT Analysis for Management Consulting. USA: Stanford Research Institute Alumni Newsletter (SRI International), 2005

17. IESR (2020): CLIMATE TRANSPARENCY REPORT COMPARING G20 CLIMATE ACTION AND RESPONSES TO THE COVID-19 CRISIS

18. IESR. (2021). Indonesia Energy Transition Outlook 2021: Tracking Progress of Energy Transition in Indonesia

19. IEA (International Energy Agency). 2017. "Unit Converter.” http://www.iea.org/ statistics/resources/unitconverter/.

20. IPCC (2014): Climate Change 2014: Synthesis Report. Contribution of Working Groups I, II and III to the Fifth Assessment Report of the Intergovernmental Panel on Climate Change [Core Writing Team, R.K. Pachauri and L.A. Meyer (eds.)]. IPCC, Geneva, Switzerland.

21. Johnson, G., Whittington, R., Scholes , K., Angwin , D., \& Regner, P. (2015). EXPLORING STRATEGY. United Kingdom: Pearson Education

22. Lindgren, M., \& Bandhold, H. (2003). Scenario Planning: The Link between future and strategy. Palgrave Macmillan

23. Porter, M. E. (1980). Competitive strategy techniques for analyzing industries and competitors. New York, Free Press.

24. Rothaermel, F. T. (2014). Strategic Management, Second edition, McGraw-Hill Education, New York, NY.

25. Serafina Muryanti Hayu P., Mr. Herry Nuryanto Kurniawan and Emir Nurmansyah. (2019). Renewable Energy in Indonesia. Lexology.com

26. World Bank. 2016. Indonesia Data (Database). http://data.worldbank.org/ country/indonesia.

27. World Bank Group. (2020). Doing Business 2020: Comparing Business Regulaiton in 190 Economies

Cite this Article Enrico Yushardi Hamdanil, Agung Wicaksono (2022). Renewable Energy Transition Strategy for PT.CI to Reduce 50\% Emission by 2030. International Journal of Current Science Research and Review, 5(1), 66-72 